\title{
Studies on different storage structures on the shelf-life of Hurrihittu (Ragi value added product) against Sitophilus oryzae
}

\author{
H.C. LATHA*, H.C. SOWMYA AND P.S. JAGADISH
}

Department of Entomology, University of Agricultural Sciences, Gandhi Krishi Vignana Kendra, BENGALURU (KARNATAKA) INDIA

\section{ARITCLE INFO}

Received : 01.01 .2014

Accepted : 10.03.2015

\section{KEY WORDS :}

Shelf-life, Ragi, Sitophilus oryzae, Storage structure, Hurrihittu

*Corresponding author:

Email: lathaent@gmail.com

\begin{abstract}
Finger millet (Eleusine corcana) is a small millet and quick growing crop, particularly suited to a dry continental climate. Finger millet value added products enhances the bioavailability of nutrients, but also improves the overall nutritional quality of grains. Diversification of diet is necessary to overcome the nutritional situation in the country. The ragi value added products infested by the storage pests lead to the qualitative and quantitative losses to overcome this losses. So, the study was conducted to know the shelf-life of Hurrihittu against Sitophilus oryzae on different storage structure like cloth bag, polythene cover, mud container, glass container and steel container. It was observed that Hurrihittu stored in the cloth bag recorded maximum numbers of insects and Hurrihittu stored in glass container was free from infestation till 150 days and infestations was recorded at 180 days. Shelf-life of Hurrihittu in cloth bag was less, whereas, Hurrihittu stored in steel container showed longer shelf-life.
\end{abstract}

How to view point the article : Latha, H.C., Sowmya, H.C. and Jagadish, P.S. (2015). Studies on different storage structures on the shelf-life of Hurrihittu (Ragi value added product) against Sitophilus oryzae. Internat. J. Plant Protec., 8(1) : 187-189. 